JELTL (Journal of English Language Teaching and Linguistics) e-ISSN: 2502-6062, p-ISSN: 2503-1848

2020, Vol. 5(3)

www.jeltl.org

\title{
Exploring English Learners' Engagement and Their Roles in the Online Language Course
}

\author{
Fatimah Mulya Sari \\ Universitas Teknokrat Indonesia \\ fatimah@teknokrat.ac.id
}

\begin{abstract}
In technology-enhanced language learning, student engagement and roles of learners are being popular to be exposed to a better understanding of their progress on their performance of learning, and possible pitfalls in the online language classes during the study-from-home program in the times of COVID-19. This article attempts to explore the students' perceptions of their engagement in the online learning process. It also investigates the prominent learners' roles in the online learning environment and the possible factors affecting their engagement or participation in the online learning process. An exploratory research design was applied to this study. The subjects were a hundred and sixty-five undergraduate students from the English Literature Department and the English Education Department. The data collected were from a questionnaire that was distributed using Google Form link via WhatsApp Group, an online interview through the ZOOM meeting, and online observation through learning management systems (LMS) Moodle used by the students. Results show that most students conveyed positive responses toward their online engagement. There were also three most prominent learners' roles identified. These roles covered active learning, problem solvers, and knowledge seeker. Besides, most students expressed that the number of compulsory task submissions, content courses, unstable internet connection, and limited internet data become the learning factors that might demotivate them to accomplish the online activities and complete the online language course. Thus, course creators or teachers should reconsider using appropriate and effective online learning activities and online learning objects to enhance the students' active engagement in the online course.
\end{abstract}

Keywords: learners' roles, online learning objects, online learning activities, student engagement

JELTL (Journal of English Language Teaching and Linguistics), 5(3), 2020 


\section{Fatimah Mulya Sari}

\section{INTRODUCTION}

The advanced technology in the education sector supports the online learning process by optimizing digital media and the use of the internet. It may provide abundant learning sources and activities that fit in Indonesian learners' characteristics and help them be independent learners (Aminatun \& Octaviani, 2019; Nurjanah \& Pratama, 2020; Putri \& Sari, 2020) and provide learners the flexibility of self-paced learning (Jung et al., 2019) whereby they may watch a series of lecture videos, take quizzes, and post their ideas in discussion forums (Wong et al., 2019). The successful online learning process is inseparable from the roles of teachers and learners. An online learning environment widens opportunities for learners to learn a language and acquire knowledge independently, enrich real-life learning experiences (Sari \& Wahyudin, 2019), and build such a productive online learning environment where spontaneous facilitation among learners might emerge for their autonomous learning. These learning situations are closely interwoven with the teacher's role as a skillful manipulator to ask a question, give commands, and other cues to elicit students' responses to create a responsive classroom (Rido \& Sari, 2018; Sari, 2018; Nurjanah \& Pratama, 2020).

Students' engagement in the teaching and learning process is essential as it is a way of stimulating active participation by doing collaborative group work and discussion, sharing comments, and sharing their ideas in a meaningful way (Farizka, Santihastuti, \& Suharjito, 2020). Darmawansah \& Indartono (2019) assert that students' engagement may increase due to web-based learning technology, teachers' support, and motivation in the classroom. They also strengthen that the outcomes of EFL students' engagement are to prove students' performance, effective educational practices, and student success. As stated by Sari \& Putri (2019), millennial language learners have a role as an active constructor of knowledge that needs to be provided by an interactive learning environment with user-friendly instructional learning media. Besides, the learners as future engineers have to possess several learning abilities to participate in discussions, explanations, formal and informal conversations, oral presentation, negotiation, persuasion, problem-solving, and conflict-resolution (Rajprasit \& Hemchua, 2015).

One of the most efficient ways of improving online learning quality is to analyze what learners are doing during online learning activities. Thus, this paper aims to answers the proposed questions, as follows:

(1) How are the students' perceptions of their engagement in the online learning process?

(2) What are the most prominent learners' roles used in the online learning process?

(3) What are the factors affecting learners' participation in the online learning process?

\section{LITERATURE REVIEW}

The online course creates flexibility for learners to have self-paced learning without the constraints of time and place (Jung et al., 2019). It might promote knowledge construction processes and create online learning environments that encourage meaningful student engagement. Studies on student engagement in the educational context have been explored for decades. Their engagement relates to the academic relevance of tasks and activities and the increase of student achievement that shows the influential factors of 
students' success in the learning process. On the other hand, relevant studies on online learners' engagement have employed different measuring methods and revealed varying learners' roles and patterns of learner engagement in the online learning process. Ferguson et al (2015) list two patterns of learners' engagement, including completer, nearly there, midway dropout, and sampler. In their study, there are two groups of completers, covering keen completers who submitted almost all assessments on time and late completers who submitted assessments late. Learners in the nearly there pattern showed their consistency to complete assessments during the course but they dropped out before the course ended. For mid-way dropout, learners visited half of the course and accomplished three to four assessments. Besides, many learners in the sampler pattern tried out the course by watching one or two videos and briefly interacted with the course activities.

Martin-Monje et al. (2017) mentioned that the most prominent student profile in language massive open online learning courses (LMOOCs) was viewers. They stated that the learners only accessed the learning materials but they did not submit the tasks or engage in the online interaction actively. In Hill's study (2013), the findings show that there were five types of learners identified in the massive open online learning courses (MOOCs). The first learner's type was no-shows in which the learners have registered but they never logged in. The second learner's type was observers that showed the learners to log in and read the learning content, but not to take any form of assessment. Drop-ins were the third learners' type that indicated that the learners perform some activities in the online learning process. Besides that, the learners were indicated to play a role as the passive participant who only viewed a course as the content to consume and did not engage with the assignments. The last learner's type was an active participant that showed the full participation of learners in the MOOCs.

Another study from Park (2015) identified that there were five levels of students' online participation from non-active participation to active participants. The learners' roles in a Facebook group were classified into active, average, passive, and very passive categories (Kasuma, 2017; Kasuma \& Wray, 2015). A study from Sampurna, KukulskaHulme, \& Stickler (2018) found out that all Indonesian learners showed visible contributions on Facebook, chat tools (WhatsApp and Line), and Google Docs.

\section{RESEARCH METHODS}

\subsection{Research Design}

An exploratory research design was applied to this current study due to the inherent simplicity, flexibility, and utility for exploring a phenomenon in-depth and measuring its prevalence. It was best suited for providing a broad insight into particular phenomena and the comprehensive summarization of specific events experienced by the participants since the focus of this study was to explore and describe the existing issue in the real-life context, especially in the field of the online learning process. Besides, it might also provide detailed information about the learners' roles in online language classes and the factors affecting learners' participation or engagement in the online learning process. Thus, this current study might discover a better understanding of the existing issues in online learning. 


\subsection{Participants}

There were a hundred and sixty-five students from the English Literature Department and the English Education Department who participated in this study. They enrolled in the full online course of Academic Reading in the fourth semester.

\subsection{Instruments}

In this present study, the research instruments used a questionnaire, interview, and observation. The questionnaire might provide large amounts of information from a large sample of participants. It consisted of twenty questions and was distributed to all respondents through Google Form. This questionnaire would obtain information about the students' perceptions of their online engagement. The results might help to categorize the learner's roles in the online learning process. Meanwhile, the interview might be useful to follow-up on the responses from the respondents after the distribution of the questionnaire. In this study, an open-ended interview was conducted online through the ZOOM meeting cloud. Fifty interviewees were chosen randomly using purposive sampling. Online observation using a tally sheet was also conducted through learning management systems used by the students.

\subsection{Data Analysis}

Questionnaire data were analyzed using the mean score and standard deviation (SD). The results were interpreted through the level of strongly disagree (1.00-1.80), disagree (1.81-2.60), neutral/moderate (2.61-3.40), agree (3.41-4.20), dan strongly agrees (4.21-5.00). Interview data were transcribed verbatim and analyzed using qualitative content analysis. Through online observation, learners' participation was analyzed by tallying output visible online. The number of postings that included initiating or starting posts and comments or reply posts in the discussion forum and the chatbox were counted as the learners' participation. This participation, then, would be categorized as the learners' roles based on six categories in Table 1, as follows:

Table: 1 Category and indicators of learners' roles

\begin{tabular}{|c|c|c|}
\hline No & Categories of learners' roles & Indicators \\
\hline 1 & Active learners & $\begin{array}{ll}\checkmark & \text { Taking initiative to ask questions in the } \\
& \text { chatbox or posting in the discussion forum } \\
\checkmark & \text { Taking initiative to share information relating } \\
& \text { to the learning materials } \\
\checkmark & \text { Taking initiative to answer the questions } \\
\checkmark & \text { Submitting task/assignment/project } \\
\checkmark & \text { Doing post-test } \\
\checkmark & \text { Following and accomplishing all online } \\
& \text { learning activities }\end{array}$ \\
\hline 2 & Problem solvers & Being able to handle a hard question \\
\hline 3 & Knowledge seekers & $\begin{array}{l}\checkmark \quad \text { Taking initiative to read learning material to } \\
\text { another source } \\
\checkmark \quad \text { Taking initiative to find another } \\
\text { supplementary learning sources }\end{array}$ \\
\hline 4 & Viewers and collectors & $\checkmark$ Accessing learning materials (e-book, lecture \\
\hline
\end{tabular}


video, slides, etc), but do not post in the discussion forum/chatbox and do not submit the assignment/post-test

$\checkmark$ Only downloading learning materials, but never doing interaction with classmates and lecturer

5 Bystanders

Only doing the first online learning activity, such as reading e-book/slides or watching a lecture video

6 Passive learners Registering for the course, but never log in

\section{FINDINGS}

This section discusses the findings of the study by exploring the prominent learners' roles in the online learning environment and finding out the possible factors affecting their participation in the online learning process. Before revealing the learners' roles and learning factors hampering their participation in the online class, the first finding might show the students' perceptions of their online engagement. This finding might be useful to describe the online activities of the students in the online learning process. Table 2 details the results of the questionnaire about students' engagement in the online learning process.

Table: 2 Students' perception of their online engagement

\begin{tabular}{|c|c|c|c|c|}
\hline No & Statements & $\mathrm{n}$ & Mean & SD \\
\hline 1 & Making sure to study online regularly. & 165 & 3,59 & 0,90 \\
\hline 2 & Participating in an online discussion. & 165 & 3,79 & 0,77 \\
\hline 3 & Taking good notes over readings, PowerPoints, or video lectures & 165 & 3,95 & 0,73 \\
\hline 4 & Listening/reading learning materials carefully. & 165 & 3,93 & 0,86 \\
\hline 5 & Conducting assignments which are then submitte & 165 & 3,84 & 0,86 \\
\hline 6 & Desiring to learn the material. & 165 & 4,04 & 0,87 \\
\hline 7 & $\begin{array}{l}\text { Having fun in online chats, discussions, or via email with the instructor or } \\
\text { other students. }\end{array}$ & 165 & 4,13 & 0,74 \\
\hline 8 & Participating actively in small-group discussion forum & 165 & 3,99 & 0,84 \\
\hline 9 & le (chat, disc & 165 & 3,95 & 0,82 \\
\hline 10 & regularly. & 165 & 3,99 & 0,91 \\
\hline 11 & ateresting to me. & 165 & 3,93 & 0,85 \\
\hline 12 & $\begin{array}{l}\text { Finding ways to make the course material relevant to my life applying it to } \\
\text { my life. }\end{array}$ & 165 & 3,78 & 1,06 \\
\hline 13 & $\begin{array}{l}\text { Asking my instructor/other students when getting problem/ difficulties in } \\
\text { online class. }\end{array}$ & 165 & 3,91 & 0,87 \\
\hline 14 & rov & 165 & 3,98 & 0,86 \\
\hline 15 & $\begin{array}{l}\text { Creating an instant messager group (WA or others) to discuss an } \\
\text { assignment or project. }\end{array}$ & 165 & 3,75 & 0,94 \\
\hline 16 & Staying up & 165 & 3,97 & 0,91 \\
\hline 17 & $\begin{array}{l}\text { Looking over class notes between getting online to make sure I understand } \\
\text { the material. }\end{array}$ & 165 & 3,87 & 1,00 \\
\hline 18 & Const & 165 & 4,09 & 0,85 \\
\hline 19 & se requiren & 165 & 3,73 & 0,77 \\
\hline 20 & Downloading additional learning sources from internet. & 165 & 3,85 & 0,89 \\
\hline
\end{tabular}




\section{Fatimah Mulya Sari}

As shown in Table 2, most students responded to positive results. Twenty statements gained a high mean score. All of them were above 3.5 points. Statement 7 achieved the highest mean score with 4.13 points. Students agreed that they had enjoyment activities such as doing online chats, online discussions through the discussion forum, or sending an email to the instructor or other students. Statement 18 and statement 6 received the second and the third high mean score with 4.09 points and 4.04 points. These statements were interrelated as students agreed that they had a great willingness to learn the material since the available materials might help them to construct their knowledge. On the other hand, the lowest mean score was in statement 1 with 3.59 points, indicating that the students ensured to study online on a regular basis.

The questionnaire's result also pointed out that seven statements gained a mean score from a range of 3.91-3.99 points. Two statements had the same mean score of 3.99 points. They were statement 8 and statement 10. In the process of online learning, students engaged actively in small-group discussion forums and shared their ideas in this forum. From statement 14, most students accepted that they would browse through the internet when they found difficulty in understanding the learning material. Then, they also stayed up on their readings of those materials. Both statement 3 and statement 9 had the same mean scores ( 3.95 points) that showed that the students wrote informative notes over reading the learning material or slides and watching video lectures. They also participated in the online chat, discussion forum, or even email. Besides, statement 4 and statement 11 also achieved the same results with a mean score of 3.93 points. They agreed to these statements showing that they listened and read the learning materials carefully, and noticing the successful learning ways to make the course interesting to them. Then, they would ask for help from their lecturer and other students when finding learning difficulties in the online class.

From the result of the questionnaire, three statements got mean scores in the range of 3.84-3.87 points. Statement 17 had a mean score of 3.87 points that showed the students to reassure their understanding by looking over their notes. They also agreed to download supplementary learning sources from the internet (statement 20). In addition, statement 5 showed a positive response from the students in which they accomplished their online tasks and submitted them online.

Lastly, there are four statements that obtained a mean score from the range of 3.73-379 points. They were statement 2 , statement 12 , statement 15 , and statement 19 . From these statements, most students agreed to take part in an online discussion, get ways to correlate the learning material with a real-life situation, create an instant messager group for sharing information and discussing the online tasks, and review the online materials to achieve online course requirements.

Importantly, the results of the questionnaire provide some facts that there are several online activities joined by the students to prove their engagement in the online learning process. These online activities might include active participation in online chats, instant messager groups such as WhatsApp Group or Line, email, and online discussion forums to do a small-group discussion or post their critical ideas. The other activities are to write notes when reading slides or learning materials from the internet, watching and listening to video lectures. Besides, the students may download the additional learning materials from the 
internet when they get difficulties in understanding the unfamiliar materials. Lastly, they also regularly check their study in online learning and find helpful ways to make the course interesting and relevant to their daily life and increase their desire to learn the learning material.

From the observation in the online course of Academic Reading, the other finding shows that there were three most prominent learners' roles during the online learning process. These roles were identified as active learners, problem solvers, and knowledge seekers. Figure 1 highlights the result of observation based on six categories of learners' roles. The result is as follows:

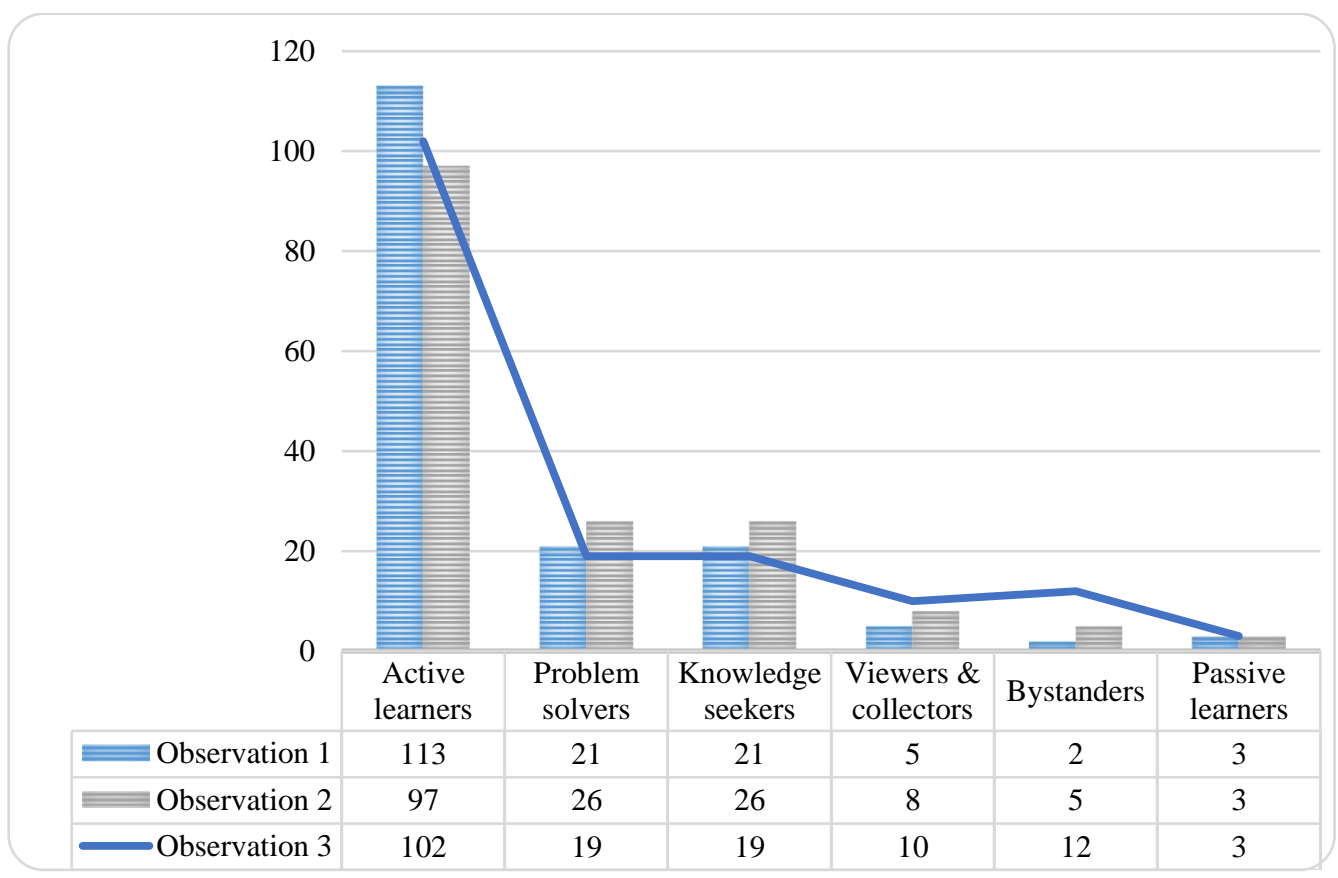

Figure: 1 Online observation through a learning management system (LMS) Moodle

As detailed can be seen in Figure 1, three learners' roles take place in high frequencies. These roles are active learners, problem solvers, and knowledge seekers. Each observation shows a different number of frequencies. The category of active learners was in the first position with total usage of 312 times. In this category, the students registered for the course, joined, and accomplished all online learning activities that were provided and facilitated by the lecturer in the Academic Reading course. They initiated to ask questions in any conversational online such as chatbox or instant messager group. They shared rational answers and responses by posting them in the discussion forum. They also participated in reading the materials from the lecturer, watching lecture videos, accomplishing a post-test in each session, and submitting online tasks. Thus, doing these activities might help them to assess their learning material mastery.

The other results from observation indicated that two categories of learners' roles obtained the same result with total usage of 66 times. These roles were problem solvers and knowledge seekers. During the online learning process, the students were able to overcome 


\section{Fatimah Mulya Sari}

any difficulty in solving difficult questions and assignments. They might ask for help from the lecturer and other students. Meanwhile, in this role of knowledge seeker, the students took the initiative to read supplementary learning materials independently. They tried to find out other meaningful learning sources that might help them to finish all activities in the online learning class. In the Academic Reading course, the lecturer provided links to ebooks, relevant journals, and web articles to help them to find additional learning sources.

Furthermore, the three least results of the learners' role category were viewers and collectors with total usage of 23 times, bystanders with total usage of 19 times, and passive learners with total usage of 9 times. From the observation, the role of viewers and collectors showed the students' online activities to access learning materials only and never post their ideas and answers in the discussion forum and post-test section. There was no interaction from these students to their lecturer and other friends. For the role of bystanders, the students only accessed the first activities by reading the slides that were provided by the lecturer in the Academic Reading course. On the other hand, the students as passive learners only did registration for the course and never join the online meeting from the beginning until the end of the semester.

From the result of the interview, there are several factors affecting the students' participation in the online learning class. The following students' interview extracts show the first online learning problems in the Academic Reading course.

\begin{tabular}{|c|c|}
\hline t.1 & $\begin{array}{l}\text { love doing online learning activities in the Academic Reading class. The } \\
\text { ecturer provided such kind of informative and useful activities in each } \\
\text { leeting. But, please reconsider the tasks. }\end{array}$ \\
\hline 3 & hen I think about compulsory task submissions, my motivation gets down... \\
\hline & Inline task submission makes me sick. Hehe. \\
\hline & $\begin{array}{l}\text {... The total of compulsory task submissions in one semester is very } \\
\text { challenging. }\end{array}$ \\
\hline 11 & Hmmm... I thought that our reading course has so many tasks. \\
\hline 17 & I can't stand with many compulsory task submissions. \\
\hline 26 & $\begin{array}{l}\text { All online activities in this course are good, except compulsory task } \\
\text { submissions. }\end{array}$ \\
\hline St.27 & $\begin{array}{l}\text { Some students said that they do not like compulsory task submissions from } \\
\text { this class, so do I. }\end{array}$ \\
\hline t.29 & I dislike the way of lecturer gives us tasks. \\
\hline t.40 & The compulsory task submissions decrease \\
\hline .43 & I prefer doing so many questions \\
\hline
\end{tabular}

The first online learning factor hampering the students' engagement or participation in the Academic Reading course is the number of compulsory task submissions. Most students stated that they enjoyed accomplishing all online learning activities, but not for the compulsory task submissions in this Academic Reading course.

Besides, the following students' interview extracts show the other online learning problems in the Academic Reading course, as follows:

\footnotetext{
St.1 Sometimes, the reading materials are too complicated to be comprehended. It took time to know the idea of the readings.

St.12 I often found out that the learning materials are uneasy to understand so it
} 

St.27 The content of the subject sometimes becomes the main learning problems in
makes me difficult to learn more. this course.
St. 30 I can say that the course content often distracts me while participating in the online discussion.
St. 48 In my point of view, the subject content or learning materials become the next factors that might give negative effects on my class participation.

From the interview's extracts, it can be seen that the content course became the online learning factor that might affect their participation in the Academic Reading course.

Then, the next factor can be seen in the following extract, as follows:
St.10 Of course, poor connection and limitation of internet data affect my active participation in the reading class.
St.13 Unstable and poor connection. Sometimes my wi-fi is not running well.
St.17I Itop participating in the online course when my provider signal is bad and affects my internet connection. And also, sometimes it is because my internet package is almost over.
St.22 My limited internet package affects my participation in this online course.
St.31 I only can say that I get an unstable internet connection, maybe because I use a cheap internet package.
St.50 I often face online problems such as bad internet connection and my internet quota is running out, in fact, there are still numerous tasks that should be finished at that time.....

From those extracts, the result shows the other learning problem that might be factors hampering the students' participation in the course. Some students mentioned that an internet connection and internet quota might influence their participation because there were a poor connection and a limitation of internet data to access the online reading course.

Thus, from the interview's extracts, it can be concluded that three factors might decrease the students' engagement in the online learning process. These factors are the compulsory task submissions, content courses, an internet connection, and internet data.

\section{DISCUSSION}

In light of results, the online learning process reveals that some educational activities are carried out by the students. The main learning activities are to read the course materials, watch the lecture video to get a direct explanation of these materials and take note of what they learn. Students may also join in the online discussion forum to deliver their ideas in a small or large group discussion. The other activity is to get involved in the online chats with the course facilitator and other classmates. These accomplishments of the online activities may prove their consistency to engage and participate in the online learning process to achieve the learning outcomes. These findings are in line with Darmawansah \& Indartono's (2019) study who found out that there are four factors of engagement effects in online learning, including skills engagement, emotion engagement, participation engagement, and performance engagement. According to them, the factor of skills engagement identifies students' activities in using proper English, listening to lecture carefully, taking notes over slides, and others. For emotional engagement, students' activities may include sharing their daily activities, giving comments and feedback during the session, having a learning effort, and good intention and feeling in the session. The factor of participation engagement 


\section{Fatimah Mulya Sari}

involves activities such as asking and initiating questions, engaging in the discussion, and knowing their teacher and other classmates. Then, performance engagement of students might be seen from their effort to do their homework and achieve excellent performance in the session. Therefore, students' engagement in the learning activities can be seen as learners' satisfaction and student capacities to be active learners that may become substantial factors in online learning (Shih et al., 2013).

Furthermore, there are three most prominent learners' roles - active learners, problem solvers, and knowledge seekers. In the online learning process, active learners' participation may not be observable, but it can be seen through the students' activity in writing a post in the discussion forum and doing the online test at the end of each session. This result is in line with Wei et al. (2015), Wang \& Member (2015), Hamdan et al. (2017), and Omar et al. (2018) who explains that writing ideas in the online discussion forum as the active participation broadens students' learning possibility to share and express the ideas that help them gain more useful knowledge and information. The learners also elicit several supplementary learning materials by browsing the internet. It provides them with authentic and real communicating English and continuously updated with current sources (Sari, 2016).

The other finding also indicates that the number of compulsory task submissions, content courses, and an internet connection and internet quota become the main factors that might affect the students' engagement and participation during the online learning process. It is in line with Kizilcec, Piech, \& Schneider's (2013) study who mention course workload as one of the major reasons for learners' disengagement in the online course. Muilenburg \& Berge (2005) and Rianto (2020) also strengthen that students find difficulty due to several influential factors such as academic skills, access to the internet, and the occurrence of technical problems in the online learning process. It is also similar to Cahyadi (2020) who states that the internet connection, internet access, and internet data should be overcome to support the online learning process. Besides, it is still doubtful for students to be engaged and interacted more in the online learning process if teachers still apply conventional teaching strategies such as lectures, presentations, and giving many tasks to their students (Corry \& Tu, 2012). Abaidoo \& Arkorful (2015) suggest teachers notice the lack of course information, developing online activities, and time limitation in online learning. Thus, educators should consider that unsuccessful online learning will happen if they do an online learning process as same as in the conventional learning process (Darmawansah \& Indartono, 2019).

\section{CONCLUSION}

More generally, these basic findings are consistent with research showing that most learners have different attitudes towards their contribution to the online learning process. They might have an accurate view of their level of participation in the online learning process. Most students expressed that the number of compulsory task submissions, content courses, and an internet connection and internet quota become the learning factor that might affect them to accomplish online language classes.

This present study has a limitation. The results' generalization is limited due to the small scope of sample size and the online course chosen. A larger group from different 
courses may have led to more varied learners' roles. This study also highlights several possibilities for future research. Future research might focus on the contents of participation from other online learning platforms that enable the researcher to explore why these learning platforms affect learners' roles. Insight into the contents of participation also allows the lecturers to provide better support for learners through different online interactive activities and learning materials in the discussion or tasks. It also needs to consider how to enrich learner's motivation so learners' roles might be improved and sustainable during an online learning process.

\section{REFERENCES}

Aminatun, D. \& Oktaviani, L. (2019). Memrise: Promoting Students’ Autonomous Learning Skill through Language Learning Application. Metathesis: Journal of English Language Literature and Teaching, 3(2), 214-223.

Anderson, A., Huttenlocher, D., Kleinberg, J., \& Leskovec, J. (2014). Engaging with Massive Online Courses. In Proceedings of the 23rd International Conference on World wide web (pp. 687-698). New York: ACM. DOI: 10.1145/2566486.2568042

Cahyadi, A. (2020). Covid-19 Outbreak and New Normal Teaching in Higher Education: Empirical Resolve from Islamic Universities in Indonesia. Dinamika Ilmu, 20(2), 255266.

Corry, M. \& Tu, C. H. (2012). Distance Education: What Works Well. Taylor and Francis. https://doi.org/10.4324/9780203050224.

Darmawansah \& Indartono, S. (2019). The Influence of Instructional Syntax to Engage EFL Students in Online Learning Environment. Indonesian Journal of English Language Teaching and Applied Linguistics, 4(1), 121-132.

Farizka, N. M., Santihastuti, A., \& Suharjito, B. (2020). Students' Learning Engagement in Writing Class: A Task-Based Learning. JELTL (Journal of English Language Teaching and Linguistics), 5(2), 203-212.

Ferguson, R., Clow, D., Beale, R., Cooper, A. J., Morris, N., Bayne, S., et al. (2015). Moving through MOOCS: Pedagogy, Learning Design and Patterns of Engagement. Proceedings of the 10th European conference on technology enhanced learning (ECTEL '15) (pp. 70-84). https://doi.org/10.1007/978-3-319-24258-3_6.

Hamdan, N. A., Mohamad, M. \& Shaharuddin, S. (2017). Hypermedia Reading Materials: Undergraduate Perceptions and Features Affecting Their Reading Comprehension. Electronic Journal of e-Learning, 15(2), 116-125.

Hill, P. (2013). Emerging Student Patterns in MOOCs: A (Revised) Graphical View. Retrieved from: http://mfeldstein.com/emerging-student-patterns-in-moocs-a-revisedgraphical-view

Jung, E., Kim, D., Yoon, M., Park, S., \& Oakley, B. (2019). The Influence of Instructional Design on Learner Control, Sense of Achievement, and Perceived Effectiveness in a Supersize MOOC Course. Computers \& Education, 128, 377-388. DOI: 10.1016/j.compedu.2018.10.001.

Kasuma, S. A. A. (2017). Four Characteristics of Facebook Activities for English Language Learning: A Study of Malaysian University Students' Needs and Preferences. Advances in Language and Literary Studies, 8(3), 155-171. DOI:10.7575/aiac.alls.v.8n.3p.155

JELTL (Journal of English Language Teaching and Linguistics), 5(3), 2020 
Kasuma, S. A. A., \& Wray, D. (2015). An Informal Facebook Group for English Language Interaction: A Study of Malaysian University Students' Perspectives, Experiences, and Behaviours. In 5th Annual International Conference on Education \& e-Learning (pp. 110). DOI:10.5176/2251-1814_EeL15.4

Kizilcec, R. F., Piech, C., \& Schneider, E. (2013). Deconstructing disengagement: Analyzing learner subpopulations in massive open online courses. 3rd International Conference on Learning Analytics and Knowledge, LAK 2013 (pp. 170-179). New York, NY Association of Computing Machinery.

Martín-Monje, E., Castrillo, M. D., \& Mañana-Rodríguez, J. (2017). Understanding Online Interaction in Language MOOCs through Learning Analytics. Computer Assisted Language Learning, 17(3), 251-272. DOI: 10.1080/09588221.2017.1378237.

Muilenburg, L. Y. \& Berge, Z. L. (2005). Student Barriers to Online Learning: A Factor Analytic Study. Distance Education, 26(1), 29-48.

Nurjanah, R. L. \& Pratama, M. R. A. (2020). Self-Regulated Learning Strategy Instructions in Reading Comprehension Skill Learning During Outbreak Era. JELTL (Journal of English Language Teaching and Linguistics), 5(2), 191-201.

Omar, A., Amir, Z., \& Mohamad, M. (2018). Facilitating Online Learning: Students' Online Discussion Strategies for a Project Work at a Technical University in Malaysia. 3L: The Southeast Asian Journal of English Language Studies, 24(4), 102-114. DOI: 10.17576/3L-2018-2404-08

Park, J. (2015). Student Interactivity and Teacher Participation: An Application of Legitimate Peripheral Participation in Higher education online learning environments. Technology, Pedagogy and Education, 24(3), 389-406. DOI: 10.1080/1475939X.2014.935743

Putri, E. \& Sari, F. M. (2020). Indonesian EFL Students' Perspectives towards Learning Management System Software. Journal of English Language Teaching and Learning, 1(1), 20-24.

Rajprasit, K. \& Hemchua, S. (2015). The English Language \& Communication in the International Workplace: An Examination of Thai Computer Engineering Professionals. 3L: The Southeast Asian Journal of English Language Studies, 21(3), 109-124.

Rianto, A. (2020). Blended Learning Application in Higher Education: EFL Learners' Perceptions, Problems, and Suggestions. Indonesian Journal of English Language Teaching and Applied Linguistics, 5(1), 55-68.

Rido, A. \& Sari, F. M. (2018). Characteristics of Classroom Interaction of English Language Teachers in Indonesia and Malaysia. International Journal of Language Education, 2(1), 40-50. DOI: 10.26858/ijole.v2i1.5246

Sampurna, J., Kukulska-Hulme, A., \& Stickler, U. (2018). Exploring Learners' and Teacher's Participation in Online Non-Formal Project-Based Language Learning. International Journal of Computer-Assisted Language Learning and Teaching (IJCALLT), 8(3), 73-90. DOI: 10.4018/ijcallt.2018070104

Sari, F. M. (2016). Internet-Based Materials in Enhancing College Students' Writing Skill Viewed from Their Creativity. Teknosastik: Jurnal Bahasa dan Sastra, 14(1), 41-45. 
Sari, F. M. (2018). Patterns of Teaching-Learning Interaction in the EFL Classroom. Teknosastik: Jurnal Bahasa dan Sastra, 16(2), 41-48.

Sari, F. M. \& Putri, S. N. (2019). Academic Whatsapp Group: Expressing Students' Experiences in Writing Class. Teknosastik: Jurnal Bahasa dan Sastra, 17(2), 56-65.

Sari, F. M. \& Wahyudin, A. Y. (2019). Undergraduate Students' Perceptions toward Blended Learning through Instagram in English for Business Class. International Journal of Language Education, 3(1), 64-73. DOI: 10.26858/ijole.v1i1.7064

Shih, H.-F., Chen, S.-H. E., Chen, S.-C., \& Wey, S.-C. (2013). The Relationship among Tertiary Level EFL Students' Personality, Online Learning Motivation and Online Learning Satisfaction. Procedia-Social and Behavioral Sciences, 103, 1152-1160.

Wang, P. A. \& Member, S. (2015). Assessment of Asynchronous Online Discussions for a Constructive Online Learning Community. International Journal of Information and Education Technology, 5(8). DOI:10.7763/IJIET.2015.V5.575

Wei, H. C., Peng, H., \& Chou, C. (2015). Can More Interactivity Improve Learning Achievement in an Online Course? Effects of College Students' Perception and Actual Use of a Course-management System on Their Learning Achievement. Computers \& Education, 83, 10-21. DOI:10.1016/j.compedu.2014.12.013

Wong, J., Khalil, M., Baars, M., Koning, B. B.-D., \& Paas, F. (2019). Exploring Sequence of Learner Activities in Relation to Self-regulated Learning in a Massive Open Online Course. Computers \& Education, 140, 1-14. DOI: 10.1016/j.compedu.2019.103595 